\title{
Developing Secondary Language Identity in the Context of Professional Communication
}

\author{
Galina V. Denissova ${ }^{a \star}$, Ekaterina A. Redkina ${ }^{\mathrm{b}}$, Anna A. Zalizniak ${ }^{\mathrm{c}}$ \\ a Department of Philology, Literature and Linguistics, Pisa State University, Pisa, Italy \\ b Department of Psychology, Lomonosov Moscow State University, Moscow, Russia \\ ${ }^{c}$ Russian Academy of Sciences, Russia \\ *Corresponding author: E-mail: galina.denissova@unipi.it
}

Background. Studying the concept of secondary language identity is one of the main problems in educational psychology since it involves the ability to use a foreign language effectively in various fields. Since languages don't exist in a vacuum but are culture-bound, a person's process of psychological transformation into having a secondary language identity entails profound psycholinguistic and psycho-sociological character changes. However, professional communication differs significantly from everyday cross-cultural communication, which means that it should be studied separately.

Objective. The aim of this paper is to propose a theoretical approach to the development of secondary language identity within professional communication.

Design. Particular interest is paid to how language is taught, and which teaching methods and techniques will ensure the development of secondary language identity in the professional context. In this article we propose that the method of foreign language teaching is one of the factors underlying the development of secondary language identity in a professional context.

Results. As professional communication is always culture-specific and culture-dependent, culture influences language teaching in two ways: linguistically and pedagogically. Linguistically, it affects the semantic, pragmatic, and discourse levels of language. Pedagogically, it influences the choice of language materials.

Conclusion. We apply the methodology of Content and Language Integrated Learning (CLIL) and the use of the translation method to analyzing the development of secondary language identity in a professional context.
Keywords:

secondary

language identity,

professional

communication,

cultural

differences,

cross-cultural

communication,

language/culture teaching, multicompetence, content and language integrated learning, translation method. 


\section{Introduction}

The main purpose of foreign language teaching can be understood as psychologically transforming a student into having the so-called "secondary culture identity," described as the process of accumulation of a set of abilities (competences) which prepare a person for foreign language communication in a multi-cultural field (Karaulov, 1987; Khaleeva, 1989; Gal'skova, 2000; Nechaev, 2014). Since language has no independent existence, foreign language teaching is culture teaching, and someone involved in learning a new language is simultaneously involved in learning a new culture.

Cross-cultural professional communication assumes that all sorts of ambiguous communicative situations occur in content-specific contexts, and therefore require developing language consciousness, particularly in professional communication. Although the development of a secondary language identity in professional communication on the surface looks different from the development of a general secondary language identity, its successful formation depends on solving the most important methodological problems, which primarily include the following:

1. understanding the process of intercultural communication as a form of joint activity realized through sharing basic categories and concepts;

2. forming internal mechanisms of awareness of tasks, conditions, and adequate means and methods of communicative activity in the context of a particular "subject matter-oriented" activity (Nechaev, 2014). The theoretical basis for such awareness lies in linguistics and linguadidactics, and the psychology of speech.

The most relevant cognitive and psychological problems involved in foreign language acquirement are well described by the phenomenon of "culture shock." This includes the learner's feelings of estrangement, loneliness, and even physical illness (Brown, 1996, p. 35), and the instantaneous "culture bump" that occurs (whether individuals are aware of it or not) "when an individual has expectations of a particular behavior within a particular situation and encounters a different behavior when interacting with an individual from another culture" (Archer, 1996, p. 171). By expectations we mean the expectations of normal behavior as learned in one's own culture. Several ramifications emerge from encountering a culture bump. These include an emotional response, a knowledge dichotomy which results in a search for information, and the formation of a perception.

The relationship between language and culture has been debated by philosophers, linguists, and social scientists alike. Philosophy has been addressing this question at least since the Ancient Greek debate between those who thought that the relationship was natural and those who considered it to be subjective and conventional. In the Middle Ages, realists claimed that words denoted concepts that corresponded to actual entities, whereas nominalists maintained that concepts only signified names or words.

The mutual relationship between language and culture, i.e. the interaction of language and culture, has long been a issue, thanks to the writings of prominent philosophers such as W. von Humboldt (1876), L. Wittgenstein (1980), T. Adorno (1993), or M. Foucault (1994); linguists such as F. de Saussure (1966), N. Chomsky (1968), or A. Wierzbicka (1997); and psychologists such as L.S. Vygotsky (1983), 
A.R. Luria (1976), or P.Ya. Galperin (1997). These are the names that first come to mind when addressing the problem of the relationship between language and culture.

Yet, the most distinguished linguists dealing with this relationship are E. Sapir (1921) and B.L. Whorf (1952). They are the scholars whose names are often used synonymously with the term "Linguistic Relativity." The core of their theory is that a) we perceive the world in terms of categories and distinctions found in our native language; and b) what is found in one language may not be found in another language due to cultural differences.

Contrary to Chomsky's theory about an innate biological basis for language (Chomsky, 1968) and the ideas of S. Pinker (Pinker, 1994) concerning language instinct, language use is social. Thus, the idea of a biological language instinct seems to be controversial in the field of linguistics: "Although there is no doubt that anything may be said in any language, the relationship between language and culture makes it easier to say certain things in some languages than in others" (Kaplan, 1996, p. 18).

The concept of the "linguistic worldview" (Humboldt's "Weltanschauung") refers to the cognitive function of language. The human being has the ability to communicate with other people by means of a system of conventional signs, which refer to classes of phenomena in extra-linguistic reality. Hence, a certain cognitive view of the world, its categorization, and the conceptualization of the perceived phenomena are encoded in the human mind. People who identify themselves as members of a certain social group acquire common ways of viewing the world through their interactions with other members of the same group. Common attitudes, beliefs, and values are reflected in the way members of the group use language, i.e. what they choose to say or not to say and how they say it. The view of the world which is established in language, is not identical to encyclopedic knowledge of the world. Languages differ among each other in this respect.

In an approach that appeals to anthropologists, psychologists, and philosophers as well as linguists, A. Wierzbicka (1997) demonstrated that every language has "key concepts" (or "inscriptions in memory"), expressed in "key words" which reflect the core values of a given culture but often have no parallel in other languages. The fact that language is culture-bound, ensures profound psycholinguistic and psycho-sociological changes during a person's psychological transformation into having a secondary language/culture identity. In a certain sense, a foreign language class seems to be the best laboratory to study how the linguistic mind works.

Teaching professional content and the skills of professional communication through a foreign language first of all requires a thorough understanding of professional cross-cultural phenomena. Secondly, it involves the application of a teaching methodology that can help students reflect on the differences between professional concepts as expressed in their L1 (native language) and in L2 (foreign language); compare and critically analyze the linguistic component; raise awareness of their own cultures; and use various skills effectively in cross-cultural professional communication, both oral and written. One such approach is Content and Language Integrated Learning (CLIL), a dual-focused approach used for teaching both content and language. Unlike other educational practices, such as bilingual education, immersion, EAL (English as an additional language), and others, CLIL provides a 
more holistic educational experience at different levels: communicative, cognitive, content, and cultural. The latter plays a particularly important role in the modern globalized world (Dalton-Puffer et al., 2010).

The dialectical connection between language and culture that determines our "inscriptions in memory" has always been a concern of foreign language (L2) educators. Whether the culture of the target language is to be incorporated into L2 teaching has been a subject of rapid change throughout the history of language teaching. For example, during the first decades of the 20th century, researchers discussed the importance and possibility of including cultural components into the L2 curriculum (Sysoyev \& Donelson, 2002). Then the advent of Communicative Language Teaching (CLT) in the late 1970s marked a critical shift for teaching culture, with the paradigm shift from an approach based largely on form and structure, to a plurality of approaches causing the unintended side effect of neglecting the issue of culture (Pulverness, 2003).

Recent studies, such as those by scholars Byram (1989, 1994), Kramsch (1993, 2001), and Ter-Minasova (2000), have focused on the seamless relationship between L2 teaching and target culture teaching, especially over the last decade. The emphasis in 20th century pedagogy was on the external goal of "behaving" in the L2 environment, rather than the internal goal of achieving better cultural attitudes or greater cognitive flexibility. Nevertheless, in many educational systems, communication is only one among many overt or covert goals, and often a subsidiary or far-distant one. Although by the mid-1980s, various advantages of teaching culture in L2 classes were virtually universally accepted, and culture was widely taught in language classes, there were still problems about what should be taught, and how culture could be taught most beneficially.

Another question that has become most acute in the contemporary world, is the interconnectedness of culture and professionalism. It is impossible to achieve professional success without cultural awareness and intercultural understanding (Jarotskaya, 2016). "If we follow the idea that culture determines the way we interpret the world, and that we use language to express this interpretation, then CLIL opens an intercultural door, where learners can have experiences which they could not have had in a monolingual setting-meaning, for example, that it provides a rich catalyst for 'living' intercultural experiences which are fundamental to a deeper understanding of global citizenship" (Coyle, Hood, \& Marsh, 2010, p. 138).

The problem is that most L2 students around the world live in a monolingual environment and consequently, they become monocultural individuals. The main task of foreign language/culture teaching therefore is the advancement of a students' ability to consciously overcome their native concepts. Language teaching means, among other things, making people think differently. In other words, it helps students to view cultural differences not as problems to be solved but as opportunities to learn more about themselves and others. "Culture associated with a language cannot be 'learned' in a few lessons about celebrations, folk songs, or costumes of the area in which the language is spoken. Cultural awareness may focus on knowledge about different cultures, but the move towards intercultural understanding involves different experiences" (Coyle, Hood, \& Marsh, 2010, p. 139).

In professional communication, the reading of content-specific texts-which is the most common teaching method-seems limited and insufficient for overcom- 
ing possible problems in cross-cultural professional communication. As for grammar books, there is still this misconception adopted both by language teachers and students, that a deep grasp of a new language's grammar will inevitably and most naturally lead to successful professional cross-cultural communication. However, in reality, learning grammar does not contribute much to the cross-cultural communicative competence which lies at the core of successful communication, both every-day and professional.

The starting point here is the concept of multi-competence, i.e. the knowledge of two or more languages in one mind. This term was devised to encompass both language systems present in the same mind, the first language and the interlanguage (Selinker, 1972). While "interlanguage" has become the standard term for the speaker's knowledge of a second language, no word existed that encompassed his or her knowledge of both the second language (L1) and the first. Hence "multicompetence" was introduced to mean "knowledge of two or more languages in one mind" (Cook, 1991, p. 115), as seen in Figure 1.

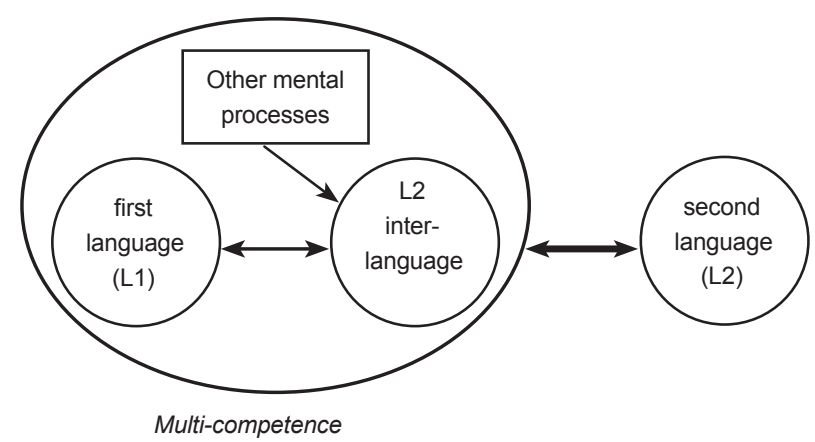

Figure 1. Model of Multi-competence (Cook, 1991)

This graphic reflects the idealized relationship between the two languages in the same mind. At one end of the continuum the two languages are quite distinct; at the other end they are completely merged; in-between come different ways in which the two languages can be linked together. Since the first language/native culture and the other language(s)/culture(s) are in the same mind, they must form a language super-system at some level rather than completely isolated systems. "Intercultural dialogue involves using skills to mediate between one's own and other cultures" (Coyle, Hood, \& Marsh, 2010, p. 141).

The cognitive sciences have provided us with simple but very useful ideas about meaningful learning, i.e. a positive approach to learning that comes from the relationship between previous knowledge (native language/culture) and new knowledge (foreign language/culture). The following four possibilities represent different points on the integrative continuum for relating the two languages in the L2 user's mind (Cook, 2003, pp. 1-18), applied to the domain of concepts:

1. L2 concepts are not acquired. The L2 user acquires the language, but not the conceptual system, and effectively uses L1 concepts with the L2.

2. The two sets of concepts exist in separate compartments. The L2 user effecttively thought-switches between the two concept-systems when appropriate. 
3. The two sets of concepts are integrated to some extent. The L2 user has partially over-lapping concept-systems.

4. A new conceptual system has been created. The L2 user thinks neither in the same way as a native speaker of the first language, nor in that of a native speaker of the second language, but in a distinctive way that differs from both. This is exactly what a secondary language/culture identity is.

Let us turn to some consequences of this for language teaching in the professional context. Learning another language means changing the contents of one's mind. Language teachers are engaged, among other things, in the task of affecting the whole minds of the students. The multi-competence idea and the changes in cognition affect not only the goals but also the techniques of language teaching. In this context we support the use of the CLIL 4Cs Framework, which includes content, communication, cognition, and culture. As a communicative approach, the CLIL teaching methodology suggests minimizing the use of L1 in the classroom. However, in what follows, we shall propose a framework for empirical research on the question why the translation method should be used in foreign language classes, and generate working hypotheses which are potentially useful for the development of a secondary language identity in professional communication.

\section{Methods}

Translation has more than one purpose. Its main aim is to serve the cross-cultural bilingual communication vehicle among people of different cultural backgrounds. That is why the problems of teaching cross-cultural professional communication and translation training are in many ways inseparable. This methodology, as opposed to the traditional practice of training for cross-cultural communication, allows students to use a foreign language effectively for the purposes of professional content-specific communication, and supports the evolution of bilingualism in the most natural way.

Translation activity, founded on the general principle of "frequency and recency of activation" (Luria, 1976; Paradis, 1993), establishes a bilingual network in the student's brain that connects each L2 unit directly with the equivalent unit of the $\mathrm{L} 1$, and reduces the frequent occurrence of those linguistic and cultural pseudoequivalents that are actually the main source of communication failures.

\section{Results}

Training for cross-cultural bilingual professional communication by means of translation may minimally be defined as the union of several rather important skills:

1.Comprehension and interpretation ability implies the application of this approach to various types of texts, considering various aspects and levels: text, reference, cohesion, and "naturalness." This competence includes reading, comprehension, and message interpretation (encoding and decoding). Translating is a discourse operation interposed between language and thought, so the skill of translating helps to develop the ability to overcome numerous obstacles. 
The first obstacle is related to reading and comprehension ability in the source language. Once the translator has coped with this obstacle, the most frequent translation difficulties are of a semantic and cultural nature. This includes such problems as "linguistic untranslatability" (cognates, i.e. calque and other forms of interference; institutional and standardized terms, neologisms, aphorisms, etc.) or cultural "untranslatability" (idioms, sayings, proverbs, jokes, puns, etc.); being able to manage losses and gains; and finding solutions to lexical ambiguity, etc., through mechanisms such as compensation, loans, explanatory notes, adaptation, equivalence, paraphrasing, analogies, etc.

One should adopt a very cautious attitude towards these words or expressions so as to avoid interference and/or language misuse. One of the greatest virtues of training in a foreign language and translation at the same time is the development of the so-called "contextualized intuition," i.e. the ability to find the nearest common sense interpretation of the "not found" element within its context, and being able to assess earnings and losses and show self-correction ability.

2. The re-wording skill means applying various strategies for the restitution of the message (recoding) by choosing the appropriate method(s), techniques, and procedures. The most frequently used procedures for the restoration of ideas contained in a translation unit call for the student to use transfer, cultural or functional equivalence, synonymy, transposition, modulation, compensation, reduction, and expansion or amplification. For this purpose, it is also indispensable for the student to make effective use of different types of documentation: parallel texts, monolingual and bilingual dictionaries, encyclopedias, term data base, informants, and other sources.

3. The ability to make constant choices, in each paragraph, sentence or translation unit, so as to decide which of them is most useful for transferring the ideas in the text being translated. Cognition, in the form of self-consciousness and selfconfidence, plays a very important role in the preparatory phase of a translation, in as much as this period implies conscious mental activities where translating problems are detected and analyzed, and information and knowledge are accumulated.

4. The capacity to generate a TT (target text) series of more than one viable term (TT1, TT2...) for a ST (source text). This skill can also help to replace a binary approach to language learning (only right and wrong) with a non-binary one which presupposes at least two right answers, as well as wrong ones.

5. The ability to select only one TT, quickly and with justified confidence, and to propose this TT as a replacement for the ST for a specified purpose and reader. It is a process of generation and selection between alternative texts that should be taught, and presumably what is usually not taught in a language class (Pym, 1992).

\section{Discussion}

Since translation remains under the tutelage of foreign language learning, this area of knowledge could be described as "linguistics applied to translation." This discipline aims to shape the following profile of L2 students: sound linguistic training in two languages; knowledge covering a wide cultural spectrum; high reading comprehension competence; adequate management of documentary sources; capacity for analysis and self-criticism; efficient data processing training at the user's level; 
and writing their own language well. Last but not least: training for cross-cultural communication by means of translation essentially interweaves the culture bump, as both a concept and as a strategy, into an intercultural communication workshop, with each step taking the student from culture bump, to culture-specific information, to an underlying universality. In sum, this approach is intended to develop the student's secondary language identity with professional language consciousness in the most profitable way.

\section{Conclusion}

Language teaching means making people think differently. Seeing, being aware of, and understanding these differences in professional communication result from applying certain methodological and teaching approaches. In order to view cultural differences not as problems to be solved but as opportunities to learn more about oneself and others, we need to turn to the problem of the formation of secondary language identity in the professional context. Understanding the role of cultural professional content in the development of secondary language identity is the crucial factor contributing to successful cross-cultural professional communication.

As for teaching approaches, communicative CLIL methodology and the translation method can be effectively combined. The CLIL approach works at a micro level of meaningful interaction between peers in the classroom, and at a macro level outside the classroom in cross- and intercultural communication. Translation is not referred to as the classical translation method, but rather as so-called "translation competence" based on cross-linguistic analysis that helps in clarifying "key concepts"/ "key words" and removing linguistic and cultural pseudoequivalents, the main source of miscommunication. Such a methodology makes it possible to most effectively use a foreign language for the purposes of practical professional communication, and provides for the evolution of bilingualism in the most natural way.

\section{Limitations}

Currently, the proposal to improve translation competence in the system of intercultural communication training based on cross-linguistic analysis, is supported only at the empirical level, and remains open not only to modifications, but to radical changes as well. In this context, the identification and analysis of the role of translation in foreign language teaching requires a strong conceptual framework before it can ensure any heuristic validity.

\section{References}

Adorno, T. (1993). The Culture Industry: Selected Essay on Mass Culture. London: Routledge.

Archer, C.M. (1996). Culture bump and beyond. In J.M. Valdes (Ed.), Culture Bound. New York: Cambridge University Press, 170-178.

Brown, H.D. (1996). Learning a second culture. In J.M. Valdes (Ed.), Culture Bound. New York: Cambridge University Press, 33-48.

Byram, M. (1989). Cultural studies in foreign language education (Vol. 46). Multilingual Matters. https://doi.org/10.1080/07908318809525025 
Byram, M. (1994). Culture and Language Learning in Higher Education. Multilingual Matters Ltd.

Chomsky, N. (1968). Language and mind. Psychology Today, 1(9), 48. https://doi.org/10.1017/ CBO9780511791222

Cook, V.J. (1991). The poverty-of-the-stimulus argument and multicompetence. Interlanguage studies bulletin (Utrecht), 7(2), 103-117. https://doi.org/10.1177/026765839100700203

Cook, V. (Ed.). (2003). Effects of the second language on the first (Vol. 3). Multilingual Matters. https://doi.org/10.21832/9781853596346

Coyle, D., Hood, P., \& Marsh, D. (2010). CLIL: Content and Language Integrated Learning. Cambridge: Cambridge University Press.

Dalton-Puffer, C., Nikula, T., \& Smit, U. (Eds.). (2010). Language use and language learning in CLIL classrooms (Vol. 7). John Benjamins Publishing. https://doi.org/10.1075/aals.7

Dawkins, R. (1999). The selfish gene [1976]. Oxford-New York.

Foucault, M. (1994). The Order of Things: An Archaeology of the Human Sciences. USA: Vintage Books.

Galperin, P.Ya. (1997). Yazykovoe soznanie i nekotorye voprosy vzaimootnosheniya yazyka i myshleniya [Language consciousness and some of the relationship between language and thought]. Voprosy filosofii [Problems of Philosophy], 4, 95-101.

Gal'skova, N. (2000). Sovremennaya metodika obucheniya inostrannym yazykam [Modern methodology of foreign language teaching]. Moscow: Arkti.

Humboldt, W. von (1876). The heterogeneity of language and its influence on the intellectual development of mankind. Retrieved from http://www.worldlibrary.org/articles/wilhelm_von_ humboldt.

Jarotskaya, L.V. (2016). Foreign language and the development of professional personality. Moscow: Moscow State Linguistic University.

Kaplan, R.B. (1996). Culture and the written language. In J.M. Valdes (Ed.), Culture Bound. New York: Cambridge University Press, 8-19.

Karaulov, Yu.N. (1987). Russkij yazyk i yazykovaya lichnost'. [Russian language and linguistic identity]. Moscow: Nauka.

Khaleeva, I.I. (1989). Osnovy teorii obucheniya ponimaniyu inoyazychnoj rechi [Fundamentals of the theory of teaching foreign speech understanding]. Moscow: Vysshaya shkola.

Kramsch, C. (1993). Context and culture in language teaching. Oxford: Oxford University Press.

Kramsch, C. (2001). Language and Culture. Oxford: Oxford University Press.

Luria, A. (1976). Basic Problems of Neurolinguistics. The Hague-Paris: Mouton. https://doi. org/10.1515/9783110800159

Nechayev, N. (2014). Psychological Patterns of Development of Students' Secondary Language Personality. Procedia - Social and Behavioral Sciences 154, 14-22. https://doi.org/10.1016/j. sbspro.2014.10.105

Paradis, M. (1993). Linguistic, psycholinguistic, and neurolinguistic aspects of "interference" in bilingual speakers: The activation threshold hypothesis. International Journal of Psycholinguistics, 9, 133-537.

Pinker, S. (1994). The Language Instinct. New York: Harper Perennial Modern Classics. https:// doi.org/10.1037/e412952005-009

Prandi, M. (2004). The Building Blocks of Meaning. Amsterdam: Benjamins. https://doi. org/10.1075/hcp.13

Pulverness, A. (2003). Distinctions \& Dichotomies: Culture-free, Culture-bound. Retrieved from http://elt.britcoun.org.pl/forum/distanddich.htm.

Pulverness, A. (2004). Here and There: Issues in Materials Development for Intercultural Learning. Retrieved from http://elt.britcoun.org.pl/forum/handt.htm. 
Pym, A. (1992). Translation error analysis and interface with language teaching. In C. Dollerup \& A. Loddegaard (Eds.) The Teaching of Translation. Amsterdam: John Benjamins, 279-288. https://doi.org/10.1075/z.56.42pym

Sapir, E. (1921). Language: An Introduction to the Study of Speech. Retrieved from http://www. bartleby.com/186/10.

Salmon, L. (2006). A Theoretical Proposal on Human Translation Processes. Cognitive Systems, 6-4, 311-334.

Saussure, F. de. (1966). Course in General Linguistics. New York: McGraw-Hill Book Company.

Selinker, L. (1972). Interlanguage. International Review of Applied Linguistics. X (3), 209-231. https://doi.org/10.1515/iral.1972.10.1-4.209

Sysoyev, P.V. \& Donelson, L.R. (2002). Teaching Cultural Identity through Modern Language: Discourse as a Marker of an Individual's Cultural Identity. Retrieved from http://www.actr. org/JER/issue4/11.

Ter-Minasova, S.G. (2000). Jazyk i mezhkul'turnaja kommunikacija [Language and Intercultural Communication]. Moskva: Slovo.

Vygotsky, L.S. (1983). Istoriya razvitiya vysshikh psikhicheskikh funkcij. In Sochinenie $v 6$ tomakh [History of the development of higher mental functions / 6 volumes], 3. Moscow: Pedagogika.

Wierzbicka, A. (1997). Understanding Cultures Through Their Key Words. Oxford University Press.

Wittgenstein, L. (1980). Culture and Value. Chicago: Chicago University Press.

Whorf, B.L. (1952). Language, Mind, and Reality. A Review of General Semantics, 9, 167-188.

Original manuscript received December 07, 2018

Revised manuscript accepted January 10, 2019

First published online February 15, 2019

To cite this article: Denissova, G.V., Redkina, E.A (2019). Developing secondary language identity in the context of professional communication. Psychology in Russia: State of the Art, 12(1), 21-30. DOI: $10.11621 /$ pir.2019.0102 